eCommons@AKU

THE AGA KHAN UNIVERSITY

Department of Medicine

Section of Haematology/Oncology

tures

January 1997

\title{
Retinoic acid syndrome radiological features
}

M. Umar Islam

Aga Khan University

Ikram A. Burney

Aga Khan University

Mohammad Khurshid

Aga Khan University, mohammad.khurshid@aku.edu

Follow this and additional works at: https://ecommons.aku.edu/

pakistan_fhs_mc_med_haematol_oncol

Part of the Oncology Commons

\section{Recommended Citation}

Islam, M., Burney, I., Khurshid, M. (1997). Retinoic acid syndrome radiological features. Acta Radiologica, 38(2), 340-340.

Available at: https://ecommons.aku.edu/pakistan_fhs_mc_med_haematol_oncol/18 


\section{Correspondence}

\section{RETINOIC ACID SYNDROME - RADIOLOGICAL FEATURES}

The treatment of acute promyelocytic leukemia (APL) with alltrans-retinoic acid (ATRA) sometimes results in a syndrome characterized by fever, respiratory distress, pleural and pericardial effusion, weight gain, and pulmonary infiltrates on chest radiography (2). We have recently observed a patient with radiological features suggesting the diagnosis of retinoic acid syndrome, which to our knowledge has not earlier been mentioned in the radiological literature.

The patient was a 23-year-old woman presenting with fever and pancytopenia. She was diagnosed as having APL and was treated with ATRA. On the fifth day of therapy, she became acutely short of breath. Her respiratory rate was accelerated, her pulse rate was $160 / \mathrm{min}$, temperature $37^{\circ} \mathrm{C}$, and blood pressure $140 / 80 \mathrm{~mm} \mathrm{Hg}$. Auscultation of the chest revealed diminished breath sounds on the left side. A chest radiograph showed alveolar infiltrates on the right side and opacification of the left hemithorax due to pleural effusion. Analysis of arterial blood gases revealed marked hypoxemia. She was managed with mechanical ventilation and $10 \mathrm{mg}$ of dexamethasone twice daily. A left-sided chest tube was placed for draining off hemorrhagic fluid, with diminution of the pleural effusion. Alveolar infiltrates persisted at the right lung base. The clinical and radiological signs further improved and there was complete resolution of the pulmonary infiltrates and the effusion by the third week.

ATRA is a normal constituent of plasma. It is probably derived physiologically by intracellular oxidation of plasma retinol that has been absorbed from the intestines $(1,7)$. When administered in therapeutic doses it produces the differentiation of immature neoplastic cells into mature granulocytes (4). Compared with most anitcancer drugs used for treating acute APL, ATRA is considered highly safe.

However, the retinoic acid syndrome develops in approximately $25 \%$ of patients (2). It may occur between the second day and the third week of treatment. Death may occur from progressive hypoxemia and multiorgan failure. Patients with APL who present with a high tumor burden or develop leukocytosis are more likely to suffer from this syndrome (7). Clinically the situation resembles the capillary leak syndrome, which results after infusion of cytokines, i.e. interleukin-2 (5). An explanation as to the pathogenesis is that the drug induces functional maturation and migratory capacity in undifferentiated leukemic cells. The migration of these cells into the lung tissue could explain the respiratory distress (3). Autopsy has displayed extensive infiltration of myeloid cells in the lung, liver, skin and kidneys (2). Recently it has been found that ATRA upregulates the integrin gene on leukocytes which enhances their adherence to the capillary endothelium and promotes focal endothelial leakage $(2,6)$

The syndrome is difficult to manage once established. Hence, early recognition of the syndrome is important. Unexplained dyspnea, weight gain and fever are good indicators. The radiographic abnormalities are nonspecific and resemble pulmonary edema or infection. The sudden appearance of pleural effusion may indicate the onset of this ominous condition.

\section{Umar Islam, Ikram A. Burney and Mohammad Khurshid Departments of Radiology, Medicine and Pathology, \\ The Aga Khan University Hospital,} Stadium Road, PO Box 3500, Karachi 74800, Pakistan

\section{REFERENCES}

1. Blomhoff A., Green M. H., Berg T. \& Morum K. R.: Vitamin A metabolism. New perspectives on absorption, transport and storage. Physiol. Rev. 71 (1991), 951.

2. Frankel S. R., Eardley B., Lauwers G., Weiss M. \& WarRELL R. P.: The retinoic acid syndrome in acute promyelocytic leukemia. Ann. Intern. Med. 117 (1991), 292.

3. Gordon M., Lakubowaski A., Frankel S., Warrell R. P. \& GabriLove J.: Neutrophil function in a patient with acute promyelocytic leukemia treated with all-trans-retinoic acid. Proc. Am. Soc. Clin. Oncol. 10 (1991), 225.

4. Hyang M. E., Ye Y. C., Chen S. R. et al.: Use of all-transretinoic acid in the treatment of acute promyelocytic leukemia. Blood 72 (1988), 567.

5. Margolin K. A., Rayner A. A., Hawkin M. J. et al.: Interleukin-2 and lymphokine-activated killer cell therapy of solid tumors. Analysis of toxicity and management guidelines. J. Clin. Oncol. 7 (1989), 486.

6. Springer T. A.: Adhesion receptors of immune system. Nature 346 (1990), 425.

7. Warrell R. P., De Hugues T., Wang Z. Y. \& Degos L.: Acute promyelocytic leukemia. N. Engl. J. Med. 329 (1993), 177. 